\title{
Efeito da Monensina e Lasalocida sobre a Atividade de Fermentação de Aminoácidos in Vitro pelos Microrganismos Ruminais ${ }^{1}$
}

\author{
Rogério de Paula Lana², Juliana Silva de Oliveira ${ }^{3,}{ }^{*}$, Arnaldo Chaer Borges ${ }^{4}$, \\ Rafael Gonçalves Veloso ${ }^{3}$, Poliana Mary Magalhães Nunes ${ }^{3,{ }^{*}}$
}

\begin{abstract}
RESUMO - Este experimento visou estudar os efeitos in vitro dos ionóforos sobre a fermentação ruminal de aminoácidos. Utilizou-se líquido de rúmen de um novilho alimentado com dieta à base de capim-elefante, acrescentando solução de tripticase, em três tratamentos (controle-C, monensina-M e lasalocida-L). Foram feitas transferências diárias de inóculos para novos tubos e, no $11^{\circ}$ dia, cada tratamento deu origem a três novos $(\mathrm{C}, \mathrm{M}, \mathrm{L})$, totalizando nove combinações $\left(2^{\mathrm{a}}\right.$ fase $)$. Do $1^{\mathrm{o}}$ ao $10^{\circ}$ dia de incubação, os ionóforos evitaram o aumento expressivo na produção de amônia comparado ao controle. Do $11^{\circ}$ ao $12^{\circ}$ dia, os ionóforos foram mais eficientes em decrescer a produção de amônia quando os mesmos estavam ausentes na $1^{\mathrm{a}}$ fase; e a lasalocida foi ainda capaz de diminuir a produção de amônia e a concentração de proteína microbiana quando a monensina estava presente na $1^{\mathrm{a}}$ fase. Do $16^{\circ}$ ao $20^{\circ}$, dia verificou-se, independentemente dos tratamentos da $1^{\text {a }}$ fase, que os ionóforos diminuíram a produção de amônia. Entretanto, os ionóforos reduziram a concentração de proteína microbiana do tratamento controle da $1^{\text {a }}$ fase e aumentaram dos tratamentos contendo ionóforos. Por outro lado, verificou-se que, ao remover os ionóforos na $2^{\mathrm{a}}$ fase, houve aumento significativo na produção de amônia, sendo que este efeito não foi detectado no $11^{\circ}$ e $12^{\circ}$ dias, provavelmente pelo efeito residual dos ionóforos.
\end{abstract}

Palavras-chave: amônia, bactéria, ionóforo, rúmen

\section{Effects of Monensin and Lasalocid on Fermentation of Amino Acids in Vitro by Mixed Ruminal Bacteria}

\begin{abstract}
The objective of this experiment was to study the in vitro effects of the ionophores on ruminal fermentation of amino acids. Rumen fluid of a steer fed an elephant-grass based diet was used in the incubations, with addition of casein hydrolysate, in three treatments (control-C; monensin-M; and lasalocid-L). Inocula were transferred into new tubes, daily and on the $11^{\text {th }}$ day of incubation, tubes from each of the treatments were used to inoculate three new tubes (C, M, L), totalizing nine combinations (second phase). From the $1^{\text {st }}$ to the $10^{\text {th }}$ day of incubation, addition of ionophores prevented increases in ammonia production compared to the control. From the $11^{\text {th }}$ to the $12^{\text {th }}$ day, the ionophores were more efficient in decreasing ammonia production when they were absent in the first phase, and lasalocid was still capable of decreasing ammonia production and microbial protein concentration when monensin was used in the first phase. From the $16^{\text {th }}$ to the $20^{\text {th }}$ day, independently of the first phase treatment, the ionophores decreased ammonia production. However, the ionophores decreased microbial protein concentration in tubes that served as control in the first phase, whereas an increase was observed in tubes treated with ionophores in the first phase. Conversely, when the ionophores were removed in the second phase, there was a significant increase in ammonia production, but this effect was not detected on the $11^{\text {th }}$ and the $12^{\text {th }}$ days, probably due to the residual effect of the ionophores.
\end{abstract}

Key Words: ammonia, bacteria, ionophore, rumen

\section{Introdução}

Monensina e lasalocida são antibióticos que aumentam a eficiência de utilização de alimentos pelos ruminantes (Goodrich et al., 1984; Russell \& Strobel, 1989). Monensina atua nas trocas de sódio e prótons através do sistema antiporte a nível de membrana celular microbiana, mas também catalisa trocas de prótons e potássio. Lasalocida atua nas trocas de metais mono ou divalentes e prótons pelo sistema antiporte (Pressman, 1976).

Em uma revisão de pesquisas com grande número de animais, Goodrich et al. (1984) verificaram que a monensina melhora a eficiência alimentar de bovinos em confinamento em $7,5 \%$, principalmente pela redução no consumo de matéria seca, e melhora o ganho

\footnotetext{
${ }^{1}$ Projeto financiado pela FAPEMIG - CBB 2583/97.

${ }^{2}$ Professor do Departamento de Zootecnia da Universidade Federal de Viçosa, CEP 36571-000, Viçosa-MG; Bolsista do CNPq. E.mail: rlana@mail.ufv.br

${ }^{3}$ Estudante de Graduação em Zootecnia - UFV; *Bolsistas de Iniciação Científica - FAPEMIG/CNPq

${ }^{4}$ Professor do Departamento de Microbiologia da Universidade Federal de Viçosa.
} 
de peso de bovinos em pastagens em 13,5\%.

Inicialmente, a monensina foi comercializada como inibidor ruminal da produção de metano, mas também reduz a produção ruminal de amônia (Dinius et al., 1976; Van Nevel e Demeyer, 1977) e, conseqüentemente, a perda ruminal de proteína. Entretanto, existe pouca informação sobre o efeito dos ionóforos no metabolismo ruminal de proteínas (Russell, 1991). Poos et al. (1979) observaram aumento na passagem de proteína de escape, mas houve redução no fluxo de proteína de origem microbiana para o intestino delgado.

Bladen et al. (1961) verificaram que as bactérias gram-negativas eram as principais responsáveis pela produção de amônia, especialmente a Prevotella ruminicola, bactéria predominante no rúmen. Newbold \& Wallace (1989) observaram que culturas de Prevotella ruminicola reduziram a atividade de transporte de peptídeos quando submetidas ao ionóforo tetronasina. Esta redução é devido ao fato dos ionóforos catalisarem o efluxo de potássio e influxo de sódio e prótons para o interior da célula microbiana e devido ao gasto de ATP para evitar a acidificação intracelular (Russell, 1987).

Por outro lado, Russell et al. (1988) e Chen \& Russell (1989) acreditam que a monensina reduz a produção ruminal de amônia pela inibição da pequena população de bactérias gram-positivas, fermentadoras obrigatórias de aminoácidos e com alta capacidade de produção de amônia. As estirpes C, SR e F, bactérias com alta atividade de desaminação, foram descobertas e reportadas por Russell et al. (1988) e Chen \& Russell (1989). Em 1993, com base no seqüenciamento do RNA ribossômico, elas foram denominadas Peptostreptococcus anaerobius, Clostridium sticklandii e Clostridium aminophilum, respectivamente (Paster et al., 1993).

Este experimento objetivou estudar os efeitos in vitro dos ionóforos monensina e lasalocida sobre a fermentação ruminal de aminoácidos. A hipótese é que, se os ionóforos forem capazes de extinguir bactérias com alta capacidade de produção de amônia, então a atividade de desaminação não retornará aos níveis controles originais, mesmo após a remoção dos ionóforos do meio de cultura. Por outro lado, se os ionóforos causam apenas a inibição do transporte de aminoácidos ao nível de membrana, então, após remoção dos ionóforos do meio de cultura, através de transferências diárias e sucessivas da cultura para meio estéril que não contenha ionóforos, ocorrerá o aumento de produção de amônia.

\section{Material e Métodos}

O presente trabalho foi realizado no Laboratório de Microbiologia de Anaeróbicos do Departamento de Microbiologia da Universidade Federal de Viçosa - UFV, em Viçosa, Minas Gerais. Utilizou-se um novilho fistulado no rúmen, alimentado com dieta de volumoso (capim-elefante), como doador de líquido de rúmen. O novilho foi alojado no Laboratório de Animais do Departamento de Zootecnia da UFV.

O líquido de rúmen foi coletado antes do arraçoamento, quando o objetivo era obter meio de cultura que apresentasse $\mathrm{pH}$ inicial elevado, e duas a três horas após o arraçoamento, para obtenção de inóculo contendo população microbiana ativa. O líquido foi coletado em diferentes locais no interior do rúmen, filtrado em quatro camadas de gaze, acondicionado em garrafa térmica com fechamento hermético e transportado imediatamente para o laboratório.

No preparo do meio de cultura, o líquido de rúmen foi centrifugado a $500 \mathrm{x} \mathrm{g}$, por 15 minutos, em temperatura abaixo de $25^{\circ} \mathrm{C}$, para sedimentação de partículas dos alimentos e protozoários. O sobrenadante foi transferido para frascos Erlenmeyer de $1000 \mathrm{~mL}$, esterilizado por duas horas a uma temperatura de $105^{\circ}$ C e resfriado para posterior utilização.

Para obtenção do inóculo, o líquido de rúmen foi coletado no dia do início do experimento e mantido em banho-maria por 30 minutos. Após as partículas alimentares flutuarem pelo acúmulo de gases e os protozoários sedimentarem, foi obtido o líquido na fase mediana do frasco, por sucção.

Utilizaram-se nas incubações $8,1 \mathrm{~mL}$ do líquido ruminal esterilizado e saturado com dióxido de carbono, acrescentado de $0,7 \mathrm{~mL}$ de inóculo, 1,0 $\mathrm{mL}$ de tripticase (Trypticase; BBL Microbiology Systems, Cockeysville, MD) $15 \%(\mathrm{p} / \mathrm{v})$ e $0,2 \mathrm{~mL}$ de etanol, contendo ou não os antibióticos monensina e lasalocida. Os antibióticos foram adicionados para atingir 5,0 $\mu \mathrm{M}$ como concentração final no meio de cultura e a incubação foi realizada a $39^{\circ} \mathrm{C}$. Foram feitas transferências diárias, em anaerobiose, até o vigésimo dia, de $0,7 \mathrm{~mL}$ do líquido (inóculo) para novos tubos de incubação.

O experimento consistiu de três tratamentos (controle-C, monensina-M e lasalocida-L) e duas repetições até o décimo dia, totalizando seis tubos de incubação/dia. No décimo primeiro dia, cada um dos três tratamentos serviu de inóculo para mais três tratamentos, totalizando nove combinações diferen- 
tes (CC, CM, CL, MC, MM, ML, LC, LM, LL) e 18 tubos de incubação/dia.

Utilizaram-se seringas separadas para medição da solução de etanol e para coleta do meio de cultura em cada tratamento, evitando-se, assim, o efeito inibitório cruzado dos antibióticos. Foram retiradas alíquotas do meio a zero e quatro horas após o início da incubação, nos dias 1, 3, 6, 10,11, 12,13,16 e 20, para análises de proteína microbiana e amônia.

As amostras coletadas foram centrifugadas em tubos eppendorf a $5200 \mathrm{x} \mathrm{g}$, por 10 minutos, sendo o sobrenadante congelado para análises de amônia. O pellet foi ressuspenso em solução salina $(0,9 \%$ de $\mathrm{NaCl})$, centrifugado e separado do sobrenadante por duas vezes, e então ressuspenso em água destilada e congelado para a determinação de proteína microbiana. As análises de amônia foram feitas pelo método colorimétrico de Chaney \& Marbach (1962) e as de proteína microbiana pelo método de Lowry et al. (1951), em duplicatas.

A atividade específica de produção de amônia (AEPA) ou atividade de desaminação pela população microbiana foi determinada, utilizando-se a seguinte fórmula:

$$
\mathrm{AEPA}=\left(\Delta \mathrm{NH}_{3} \times 1.000 .000\right) /
$$

(proteína microbiana * tempo de incubação) em que: $\Delta \mathrm{EPA}=\mathrm{nmol} \mathrm{NH}_{3} / \mathrm{mg}$ proteína microbiana/ minuto; $\Delta \mathrm{NH}_{3}=$ concentração final $(4 \mathrm{~h})$ - inicial de amônia $(0 \mathrm{~h})$, em mM; Proteína microbiana = concentração inicial, em mg/L; Tempo de incubação, em minutos (240 minutos).

As análises estatísticas foram realizadas utilizando-se o procedimento ANOVA do Minitab (Ryan \& Joiner, 1994). Na primeira fase, utilizou-se modelo de regressão em função do período experimental e, na segunda fase, teste de média em dois períodos distintos (11-12 ${ }^{\circ}$ dia e $16-20^{\circ}$ dia). A opção pelo método de regressão na primeira fase foi devido à incubação das amostras serem feitas somente em duplicata (três tratamentos $\mathrm{x}$ duas repetições), não sendo possível fazer teste de média. Por outro lado, a opção pelo teste de média na segunda fase foi para facilitar a interpretação dos resultados, focalizando apenas os efeitos de tratamentos (principais e interações).

\section{Resultados e Discussão}

A Figura 1 apresenta a produção de amônia, a concentração inicial de proteína microbiana e a atividade de desaminação em 4 horas de incubação por microrganismos ruminais em um meio contendo caseína hidrolisada ( $15 \mathrm{mg} / \mathrm{L}) \mathrm{sem}$ (controle) ou com adição de monensina $(5 \mu \mathrm{M})$ ou lasalocida $(5 \mu \mathrm{M})$ (primeira fase experimental). Houve efeito cúbico de tempo $(\mathrm{P}<0,01)$ e interação quadrática de tempo $\mathrm{x}$ tratamento $(\mathrm{P}<0,05)$ sobre a produção de amônia onde, com o passar dos dias, os antibióticos evitaram o aumento expressivo na produção da mesma, provavelmente inibindo o aumento da população microbiana com alta capacidade de desaminação de aminoácidos.

Bladen et al. (1961) verificaram que a maior parte da amônia produzida no rúmen era proveniente da população de bactérias fermentadoras de carboidratos não-estruturais. Apesar destas bactérias corresponderem à maioria da população microbiana, elas apresentavam menor taxa de produção de amônia que a população microbiana mista ruminal (Russell, 1983). Na última década, foram isoladas bactérias com elevada atividade de desaminação, em pequeno número na população total (Yang \& Russell, 1993; Krause \& Russell, 1996), sendo as responsáveis pelo aumento da produção de amônia observada na população microbiana mista ruminal (Russell et al., 1988; Chen \& Russell, 1989; Paster et al., 1993). Entretanto, estas bactérias são inibidas pelos ionóforos, conforme observado por Russell et al. (1988) e Chen \& Russell (1989).

O aumento da produção de amônia no tratamento controle foi intensificado a partir do $6^{\circ}$ dia experimental. Lana \& Russell (1996), ao analisar a resistência à perda do potássio intracelular pela população microbiana de animais recebendo antibióticos, verificaram que a população atingiu o máximo de tolerância ao antibiótico a partir do $5^{\circ}$ dia do início do fornecimento de antibiótico aos animais. Verifica-se, portanto, que a nova população microbiana atingiu sua estabilidade a partir do $5^{\circ}$ ou $6^{\circ}$ dia do início do fornecimento de antibióticos, in vitro e in vivo.

Não houve efeito de antibiótico sobre a concentração inicial de proteína microbiana $(\mathrm{P}>0,05)$, mas houve um ligeiro aumento linear da mesma $(\mathrm{P}<0,01)$. Houve efeito cúbico de tempo $(\mathrm{P}<0,01)$ sobre a atividade de desaminação pela população microbiana e efeito inibitório de antibióticos $(\mathrm{P}<0,001)$, onde a lasalocida foi o mais potente inibidor $(\mathrm{P}<0,05)$ (Figura 1 ).

A Figura 2 apresenta os efeitos de tratamentos (controle e ionóforos) sobre a produção de amônia, concentração inicial de proteína microbiana e atividade de desaminação, durante a segunda fase da incubação $\left(11^{\circ}\right.$ ao $20^{\circ}$ dia), por populações de microrga- 

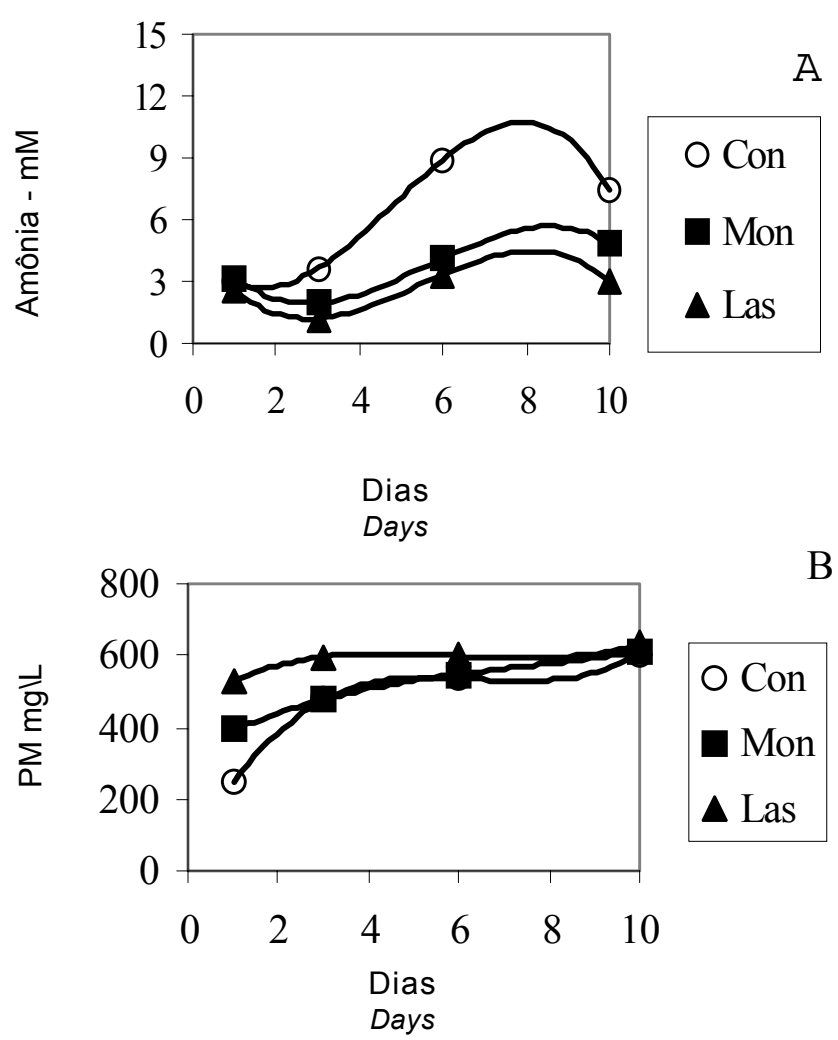

B

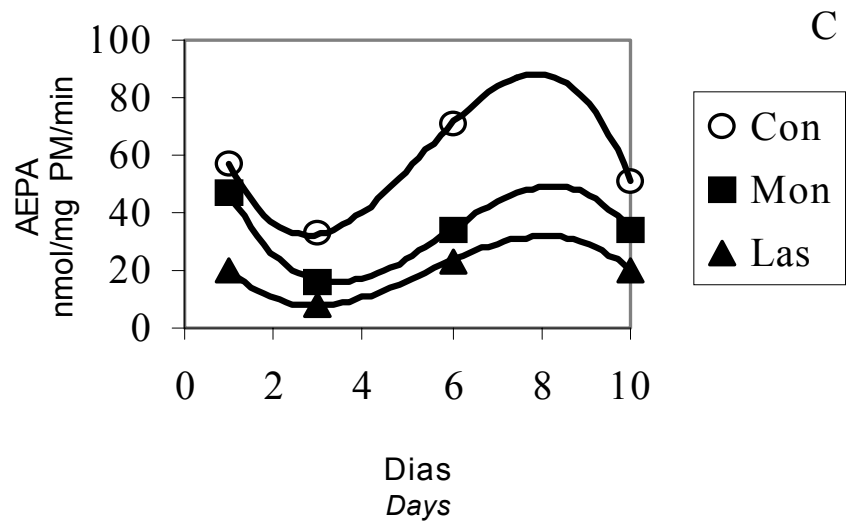

Figura 1 - Efeito de tratamentos (controle; monensina, $5 \mu \mathrm{M}$; e lasalocida, $5 \mu \mathrm{M}$ ) sobre a produção de amônia, concentração inicial de proteína microbiana e atividade de desaminação por microrganismos ruminais, em quatro horas de incubação e transferência diária de inóculo, em um meio contendo caseína hidrolisada $(15 \mathrm{mg} / \mathrm{L})\left(1^{\text {a }}\right.$ fase $)$.

Figure 1 - Effect of treatments (control; monensin, $5 \mu \mathrm{M}$; and lasalocid, $5 \mu \mathrm{M}$ ) on ammonia production, initial microbial protein concentration and deamination activity by ruminal microorganisms, after four hours of incubation and daily transfer of inoculum, in a medium containing hydrolisate of casein (15 mg/L) (1 ${ }^{\text {st }}$ phase).

nismos ruminais mantidas na primeira fase $\left(1^{\circ}\right.$ ao $10^{\circ}$ dia) sob os tratamentos controle, monensina e lasalocida. Os dados dos ionóforos monensina e lasalocida foram agrupados, pois conforme verifica-se nas Tabelas 1 e 2, não houve diferença estatística entre os mesmos.

A Tabela 1 demonstra os resultados das análises estatísticas do $11^{\circ}$ ao $12^{\circ}$ dia de incubação ( $2^{\mathrm{a}}$ fase), em que verifica-se efeito significativo dos contrastes 1, 3, 5 e 8 sobre os parâmetros avaliados $(\mathrm{P}<0,05)$. Em síntese, houve maior produção de amônia, concentração de proteína microbiana e atividade específica de produção de amônia (AEPA) ou atividade de desaminação, quando os microrganismos ruminais eram mantidos na ausência de ionóforos na primeira fase; os ionóforos foram mais eficientes em decrescer a produção de amônia e AEPA na segunda fase, quando os mesmos estavam ausentes na primeira fase; e a lasalocida foi capaz de diminuir a produção de amônia e a concentração de proteína microbiana na segunda fase, quando a monensina estava presente na primeira fase.

Trabalho apresentado por Lana \& Russell (1996) também demonstrou que o ionóforo lasalocida é mais potente inibidor da população microbiana mista ruminal in vitro que a monensina, uma vez que houve menor necessidade de lasalocida que monensina (141 vs $178 \mathrm{nM}$ ) para causar metade da perda máxima de potássio intracelular pelos microrganismos ruminais de animais em dietas de volumoso e sem ionóforos.

Os resultados das análises estatísticas do $16^{\circ} \mathrm{e}$ $20^{\circ}$ dia de incubação ( $2^{\mathrm{a}}$ fase) são apresentados na Tabela 2, na qual se verifica efeito significativo dos contrastes 3 e 5 sobre os parâmetros avaliados $(\mathrm{P}<0,05)$. Independentemente dos tratamentos da primeira fase, os antibióticos diminuíram a produção de amônia e AEPA na segunda fase. Por outro lado, os antibióticos reduziram a concentração de proteína microbiana do tratamento controle da primeira fase e aumentaram dos tratamentos contendo antibióticos.

Embora os antibióticos tenham diminuído a produção de amônia e AEPA na segunda fase, independentemente dos tratamentos da primeira fase, verifica-se que, ao se remover os antibióticos na segunda fase, houve aumento significativo na AEPA. Este efeito não foi detectado nos dias 11 e 12, provavelmente pelo efeito residual dos ionóforos.

Bladen et al. (1961) verificaram que as bactérias gram-negativas eram as principais responsáveis pela produção de amônia, especialmente a Prevotella ruminicola, uma das espécies predominantes no rúmen. Russell et al. (1988) e Chen \& Russell (1989), 


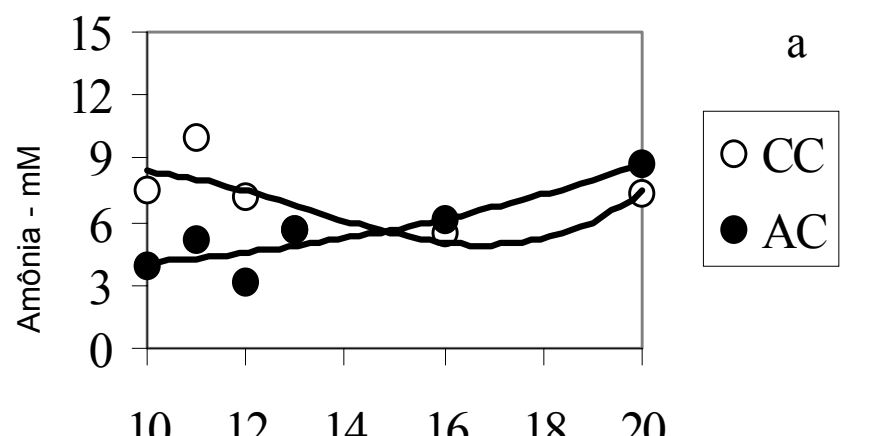

$\begin{array}{llllll}10 & 12 & 14 & 16 & 18 & 20\end{array}$

Dias

Days
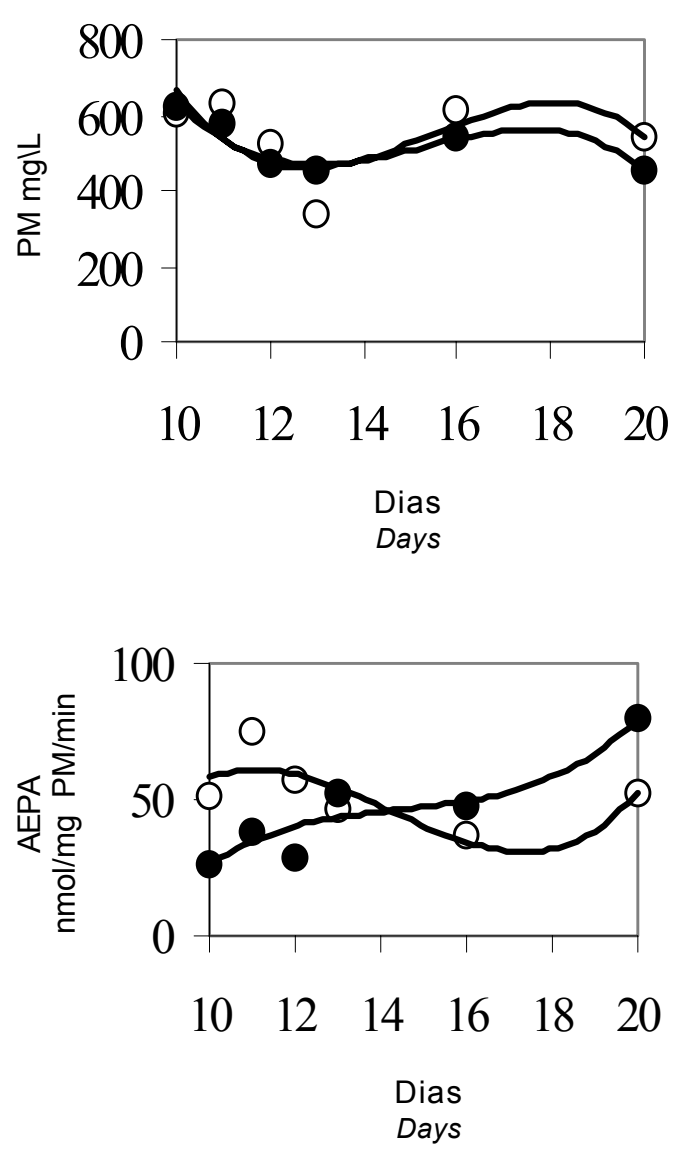

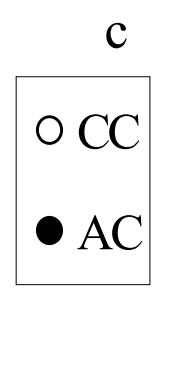

e

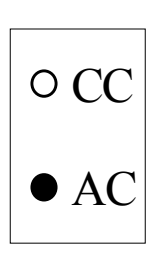

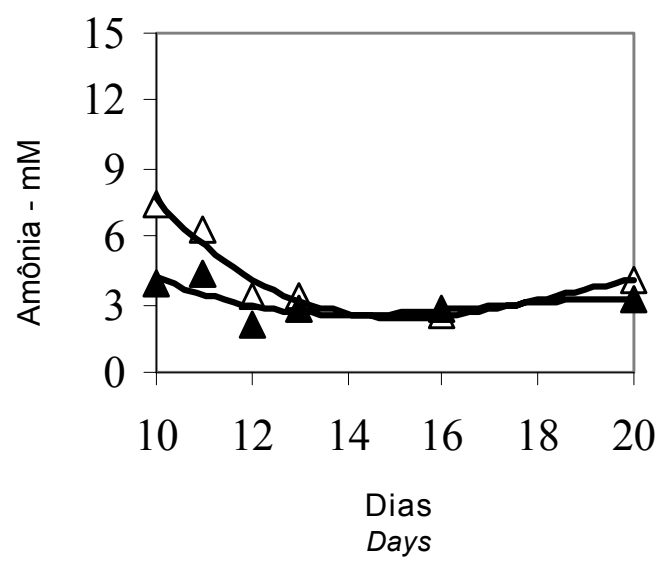

$\mathrm{b}$

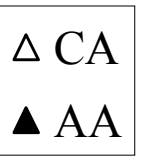

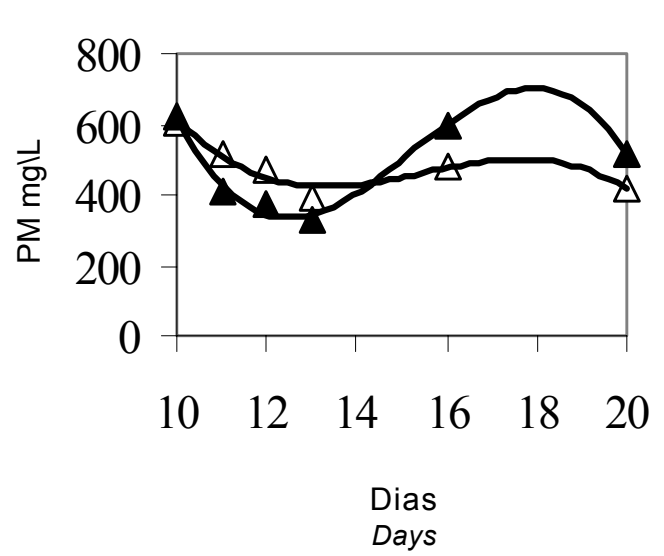
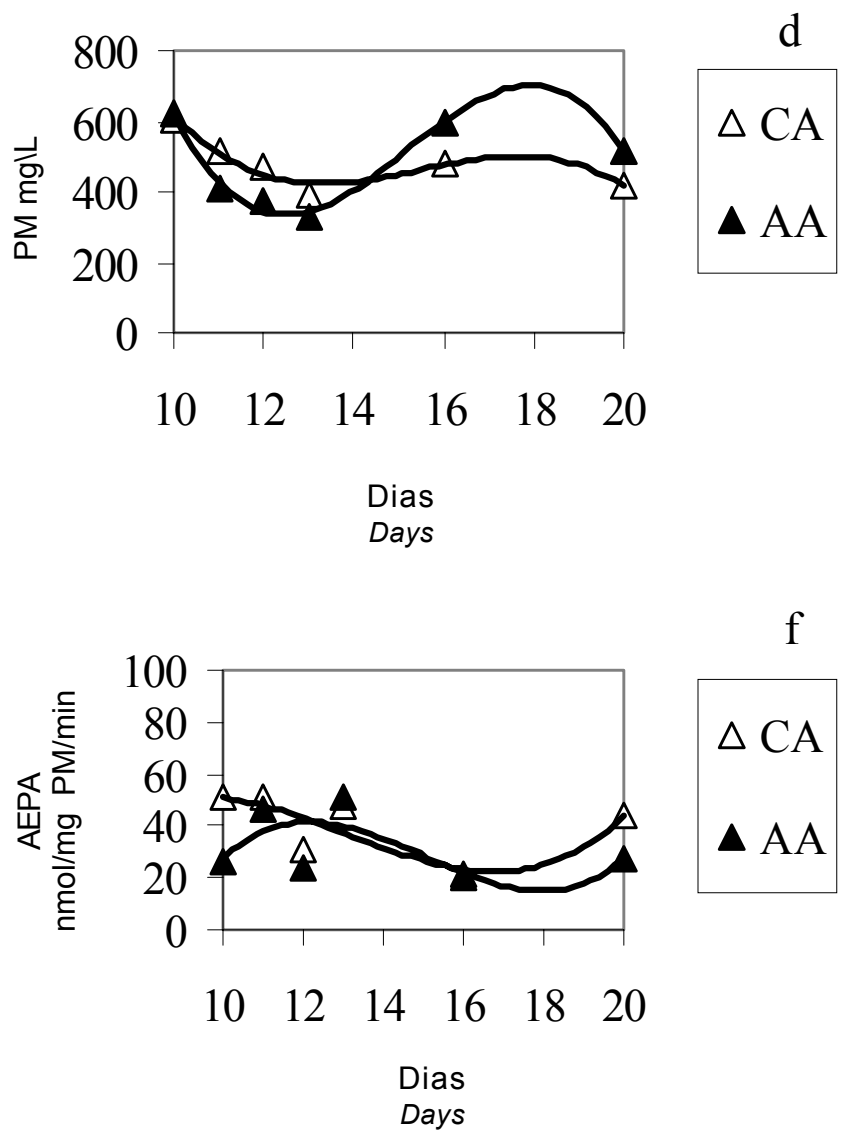

Figura 2 - Efeito de tratamentos (controle-C; e antibiótico-A = $5 \mu \mathrm{M}$ de monensina ou lasalocida) sobre a produção de amônia, concentração inicial de proteína microbiana e atividade de desaminação, por microrganismos ruminais em um meio contendo caseína hidrolisada $(15 \mathrm{mg} / \mathrm{L})$, durante a segunda fase de incubação. As duplas de letras contidas nas legendas correspondem ao tratamento da primeira ( $1^{\circ}$ ao $10^{\circ}$ dia) e segunda fases experimentais $\left(11^{\circ}\right.$ ao $20^{\circ}$ dia), respectivamente.

Figure 2 - Effect of treatments (control-C; and antibiotic- $A=5 \mu \mathrm{M}$ monensin or lasalocid) on ammonia production, initial microbial protein concentration and deamination activity by ruminal microorganisms in a media containing hydrolisate of casein $(15 \mathrm{mg} / \mathrm{L})$, during the second phase of incubation. The pair of letters contained in the legend boxes corresponds to the treatment of the first ( $1^{\text {st }}$ to $10^{\text {th }}$ day) and second experimental phases (11 th to $20^{\text {th }}$ day), respectively. 
Tabela 1 - Efeito de antibióticos sobre a fermentação de caseína hidrolisada (15 mg/L) por microrganismos ruminais, do $11^{\circ}$ ao $12^{\circ}$ dia de incubação ( $2^{\mathrm{a}}$ fase), após 10 dias de transferências diárias de inóculo ( $1^{\mathrm{a}}$ fase $)$ em um meio contendo o tratamento controle $(\mathrm{C})$, monensina $(\mathrm{M} ; 5 \mu \mathrm{M})$ ou lasalocida $(\mathrm{L} ; 5 \mu \mathrm{M})$

Table 1 - Effect of antibiotics on fermentation of hydrolizate of casein (15 mg/L) by ruminal microorganisms, from the $11^{\text {th }}$ to the $12^{\text {th }}$ day of incubation ( $2^{\text {nd }}$ phase), after 10 days of daily transfer of inoculum ( $1^{\text {st }}$ phase) in a medium containing the control treatment (C), monensin (M; $5 \mu M)$ or lasalocid (L; $5 \mu M)$

\begin{tabular}{|c|c|c|c|c|c|c|c|c|c|c|c|}
\hline \multirow{2}{*}{$\begin{array}{l}1^{\mathrm{a}} \text { fase: } \\
1^{\text {st }} \text { phase: } \\
2^{\mathrm{a}} \text { fase: } \\
2^{\text {nd }} \text { phase: }\end{array}$} & \multicolumn{3}{|c|}{$\begin{array}{c}\text { Controle } \\
\text { Control }\end{array}$} & \multicolumn{3}{|c|}{$\begin{array}{c}\text { Monensina } \\
\text { Monensin }\end{array}$} & \multicolumn{3}{|c|}{$\begin{array}{c}\text { Lasalocida } \\
\text { Lasalocid }\end{array}$} & \multirow{2}{*}{$\begin{array}{l}\mathrm{EP}^{\mathrm{b}} \\
S E^{b}\end{array}$} & \multirow{2}{*}{$\begin{array}{c}\text { Contraste }^{\mathrm{a}} \\
\text { signif. } \\
(\mathrm{P}<0,05)\end{array}$} \\
\hline & $\mathrm{C}$ & $\mathrm{M}$ & $\mathrm{L}$ & $\mathrm{C}$ & $\mathrm{M}$ & $\mathrm{L}$ & $\mathrm{C}$ & $\mathrm{M}$ & $\mathrm{L}$ & & \\
\hline $\mathrm{NH}_{3}$, & 8,60 & 5,00 & 4,68 & 4,27 & 4,77 & 1,78 & 4,02 & 3,04 & 3,30 & 0,75 & $1,3,5,8$ \\
\hline $\begin{array}{l}\mathrm{mM} \\
\text { Pmic }^{\mathrm{c}}\end{array}$ & 580 & 548 & 446 & 591 & 504 & 292 & 452 & 329 & 436 & 47,80 & $1,3,8$ \\
\hline $\mathrm{AEPA}^{\mathrm{d}}$ & 66,1 & 37,9 & 43,8 & 30,9 & 37,7 & 25,3 & 36,6 & 44,0 & 33,0 & 9,52 & 1,5 \\
\hline
\end{tabular}

a 1= Per 1 - CxML; 2 = Per $1-$ MxL; 3 = Per 2 - CxML; 4 = Per $2-$ MxL; 5 = Per 1 - CxML x Per 2 - CxML; 6 = Per 1 - CML x Per 2 - ML; 7 = Per 1 - ML x Per 2 - CxML; 8 = Per $1-$ ML x Per $2-M L$

b Erro-padrão da média.

c Proteína microbiana, $\mathrm{mg} / \mathrm{L}$.

d Atividade específica de produção de amônia, em $\mathrm{nmol} \mathrm{NH}_{3} / \mathrm{mg}$ proteína microbiana/minuto.

a $1=$ Per $1-C x M L ; 2=$ Per $1-M x L ; 3=$ Per $2-C x M L ; 4=$ Per $2-M x L ; 5=$ Per $1-C x M L$ x Per $2-C x M L ; 6=$ Per $1-C M L \times$ Per $2-$ ML; $7=$ Per $1-$ ML x Per $2-C x M L$; $8=\operatorname{Per} 1-M L \times$ Per $2-M L$

b Standard error of mean.

c Microbial protein, $\mathrm{mg} / \mathrm{L}$.

d Specific activity of ammonia production, in $\mathrm{nmol} \mathrm{NH}_{3} / \mathrm{mg}$ microbial protein/minute.

por outro lado, afirmaram que a redução da produção de amônia causada pela monensina é devido à inibição da pequena população de bactérias gram-positivas com alta produção de amônia. Uma vez que houve aumento na produção de amônia quando removeu-se a monensina do meio de cultura neste experimento, os dados obtidos comprovam que os antibióticos apenas inibem, e não extinguem, as bactérias gram-positivas produtoras de amônia.

Confirmando os resultados obtidos, Newbold \& Wallace (1989) observaram que culturas de Prevotella ruminicola reduziram a atividade de transporte de peptídeos, quando submetidas ao ionóforo tetronasina. Esta redução é devido aos ionóforos catalisarem o efluxo de potássio e influxo de sódio e prótons para o interior da célula microbiana e devido ao gasto de

Tabela 2 - Efeito de antibióticos sobre a fermentação de caseína hidrolisada (15 mg/L) por microrganismos ruminais, no $16^{\circ}$ e $20^{\circ}$ dias de incubação ( $2^{\mathrm{a}}$ fase), após 10 dias de transferências diárias de inóculo ( $1^{\mathrm{a}}$ fase $)$ em um meio contendo o tratamento controle $(\mathrm{C})$, monensina $(\mathrm{M} ; 5 \mu \mathrm{M})$ ou lasalocida $(\mathrm{L} ; 5 \mu \mathrm{M})$

Table 2 - Effect of antibiotics on fermentation of hydrolizate of casein $(15 \mathrm{mg} / \mathrm{L})$ by ruminal microorganisms, from $16^{\text {th }}$ to $20^{\text {th }}$ day of incubation $\left(2^{\text {nd }}\right.$ phase), after 10 days of daily transfer of inoculum ( $1^{\text {st }}$ phase) in a media containing the treatment control (C), monensin (M; $5 \mu \mathrm{M})$ or lasalocid (L; $5 \mu \mathrm{M})$

\begin{tabular}{|c|c|c|c|c|c|c|}
\hline \multirow{2}{*}{$\begin{array}{l}1^{\mathrm{a}} \text { fase } \\
1^{\text {st }} \text { phase } \\
2^{\mathrm{a}} \text { fase } \\
2^{\text {nd }} \text { phase }\end{array}$} & \multicolumn{2}{|c|}{$\begin{array}{l}\text { Controle } \\
\text { Control }\end{array}$} & \multicolumn{2}{|c|}{$\begin{array}{l}\text { Monensina/Lasalocida } \\
\text { Monensin/Lasalocid }\end{array}$} & \multirow{2}{*}{$\begin{array}{l}\mathrm{EP}^{\mathrm{b}} \\
S E^{b}\end{array}$} & \multirow{2}{*}{$\begin{array}{c}\text { Contraste }^{\mathrm{a}} \\
\text { signif. } \\
(\mathrm{P}<0,05)\end{array}$} \\
\hline & $\mathrm{C}$ & $\mathrm{M} / \mathrm{L}$ & $\mathrm{C}$ & $\mathrm{M} / \mathrm{L}$ & & \\
\hline $\begin{array}{c}\mathrm{NH}_{3}, \\
\mathrm{MM}\end{array}$ & 6,42 & 3,31 & 7,41 & 3,02 & 1,01 & 3 \\
\hline Pmic $^{\mathrm{c}}$ & 574 & 449 & 499 & 555 & 45,21 & 5 \\
\hline $\mathrm{AEPA}^{\mathrm{d}}$ & 44,8 & 32,6 & 63,7 & 23,8 & 8,54 & 3,5 \\
\hline
\end{tabular}

a $1=$ Per 1 - CxML; 2 = Per $1-$ MxL; 3 = Per 2 - CxML; 4 = Per $2-$ MxL; 5 = Per 1 - CxML x Per 2 - CxML; 6 = Per 1 - CML x Per $2-$ ML; 7 = Per 1 - ML x Per 2 - CxML; 8 = Per 1 - ML x Per $2-$ ML.

${ }^{\mathrm{b}}$ Erro-padrão da média.

c Proteína microbiana, $\mathrm{mg} / \mathrm{L}$.

${ }^{\mathrm{d}}$ Atividade específica de produção de amônia, em $\mathrm{nmol} \mathrm{NH}_{3} / \mathrm{mg}$ proteína microbiana/minuto.

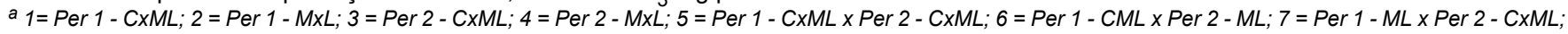
$8=$ Per $1-M L \times$ Per $2-M L$.

${ }^{b}$ Standard error of mean.

${ }^{c}$ Microbial protein, $\mathrm{mg} / \mathrm{L}$.

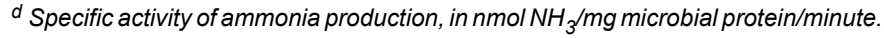


ATP para evitar a acidificação intracelular (Russell, 1987). Uma vez que a difusão facilitada também atua no transporte de aminoácidos (Driessen et al., 1987; Chen \& Russell, 1990), e esta não é afetada pelos ionóforos, não há inibição total do transporte de aminoácidos e nem da atividade de desaminação. $\mathrm{O}$ restabelecimento do transporte em sua capacidade total ocorre assim que os ionóforos são removidos do meio de cultura ou da alimentação animal, conforme observado neste experimento.

\section{Conclusões}

A monensina e a lasalocida apresentaram-se altamente eficientes em reduzir a produção de amônia de cultura de microrganismos ruminais em meio contendo caseína hidrolisada.

Houve retorno à produção normal de amônia assim que os ionóforos foram removidos do meio de cultura, provavelmente devido ao restabelecimento da população de bactérias produtoras de amônia, demonstrando que os antibióticos apenas inibem estes microrganismos.

\section{Literatura Citada}

BLADEN, H.A.; BRYANT, M.P.; DOETSCH, R.N. A study of bacterial species from the rumen which produce ammonia from protein hydrolyzate. Applied and Environmental Microbiology, v.9, p.175-180, 1961.

CHANEY, A.L.; MARBACH, E.P. Modified reagents for determination of urea and ammonia. Clinical Chemistry, v.8, p.130-132, 1962.

CHEN, G.; RUSSELL, J.B. More monensin-sensitive, ammoniaproducing bacteria from the rumen. Applied and Environmental Microbiology, v.55, p.1052-1057, 1989.

CHEN, G.; RUSSELL, J.B. Transport and deamination of amino acids by a gram-positive, monensin sensitive ruminal bacterium. Applied and Environmental Microbiology, v.56, p.2186-2192, 1990.

DINIUS, D.A.; SIMPSON, M.S.; MARSH, P.B. Effect of monensin fed with forage on digestion and the ruminal ecosystem of steers. Journal of Animal Science, v.42, p.229-234, 1976.

DRIESSEN, A.J.M.; JONG, S.D.; KONINGS, W.N. Transport of branched-chain amino acids in membrane vesicles of Streptococcus cremoris. Journal of Bacteriology, v.169, p.5193-5200, 1987.

GOODRICH, R.D.; GARRETT, J.E.; GAST, D.R. et al. Influence of monensin on the performance of cattle. Journal of Animal Science, v.58, p.1484-1498, 1984.

KRAUSE, D.O.; RUSSELL, J.B. An rRNA approach for assessing the role of obligate amino acid-fermenting bacteria in ruminal amino acid degradation. Applied and Environmental Microbiology, v.62, p.815-821, 1996.
LANA, R.P.; RUSSELL, J.B. Use of potassium depletion to assess adaptation of ruminal bacteria to ionophores. Applied and Environmental Microbiology, v.62, n.12, p.44994503, 1996.

LOWRY, O.H.; ROSEBROUGH, N.J.; FARR, A.L. et al. Protein measurement with the Folin phenol reagent. Journal of Biological Chemistry, v.193, p.265-275, 1951.

NEWBOLD, C.J.; WALLACE, R.J. Changes in the rumen bacterium, Bacteroides ruminicola, grown in the presence of the ionophore, tetronasin. Australian-Asian Journal of Animal Science, v.2, p.452-453, 1989.

PASTER, B.J.; RUSSELL, J.B.; YANG, C.-M.J. et al. Phylogeny of the ammonia-producing ruminal bacteria, Peptostreptococcus anaerobius, Clostridium sticklandii and Clostridium aminophilum. sp. nov. International Journal Systematica of Bacteriology, v.43, p.107-110, 1993.

POOS, M.I.; HANSON, T.L.; KLOPFENSTEIN, T.J. Monensin effects on diet digestibility, ruminal protein bypass and microbial protein synthesis. Journal of Animal Science, v.48, p.1516-1524, 1979.

PRESSMAN, B.C. Biological applications of ionophores. Annual Review of Biochemistry, v.45, p.501-530, 1976.

RUSSELL, J.B. Fermentation of peptides by Bacterioides ruminicola $\mathrm{B}_{1} 4$. Journal of Dairy Science, v.76, p.826830, 1983.

RUSSELL, J.B. A proposed model of monensin action in inhibiting ruminal bacteria growth: effects on ion flux and proton motive force. Journal of Animal Science, v.64, p. 1519-1525, 1987.

RUSSELL, J.B. A re-examination of the amino acid sparing effect of ionophores. In: GRAZING LIVESTOCK NUTRITION CONFERENCE, 1991, ITHACA, NY. Proceedings... ITHACA: USDA-ARS and Departament of Microbiology, Cornell University, 1991.

RUSSELL, J.B.; STROBEL, H.J. Minireview. Effect of ionophores on ruminal fermentation. Applied and Environmental Microbiology, v.55, p.1-6, 1989.

RUSSELL, J.B.; STROBEL, H.J.; CHEN, G. The enrichment and isolation of a ruminal bacterium with a very high specific activity of ammonia production. Applied and Environmental Microbiology, v.54, p.872-877, 1988.

RYAN, B.F.; JOINER, B.L. Minitab handbook. 3.ed. Belmont, CA: Duxbury Press, 1994. 448p.

Van NEVEL, C.J.; DEMEYER, D.I. Effect of monensin on rumen metabolism in vitro. Applied and Environmental Microbiology, v.34, p.251-257, 1977.

YANG, C.-M.J.; RUSSELL, J.B. Effect of monensin on the specific activity of ammonia production by ruminal bacteria and disappearance of amino nitrogen from the rumen. Applied and Environmental Microbiology, v.59, p.3250-3254, 1993.
Recebido em: 22/03/01 Aceito em: 12/11/01 